How to cite: Martan, F., Ungureanu, D. (2020) Water Quality Control Using Intake Towers in Brădișor Reservoir, Romania. 2020 "Air and Water - Components of the Environment" Conference Proceedings, Cluj-Napoca, Romania, p. 147-156, DOI: 10.24193/AWC2020_14.

\title{
WATER QUALITY CONTROL USING INTAKE TOWERS IN BRĂDIȘOR RESERVOIR, ROMANIA
}

\author{
Florian MARTAN ${ }^{1}$, Daniel UNGUREANU ${ }^{1}$
}

DOI: 10.24193/AWC2020_14

\begin{abstract}
This article presents a study, which describes a clear comparison and analysis of the raw water quality parameters taken from different levels of Brădişor reservoir using intake towers based on raw water analyses taken during the years 2015-2019. The design of the intake towers structure has a significant influence on water quality. The basic function of intake structure is to help in safely withdrawing water from the source and then to discharge this water into the discharge pipe, through which it reaches the water treatment plant or to other utilities.

The structure of intake towers is vertical, with one or more opening gates located at different depths, used for extracting water from lake taking into account the quality of raw water.
\end{abstract}

Keywords: intake structure, water quality, lake

\section{INTRODUCTION}

Study of lakes and surface water reservoir are the planet's most important fresh water resources and provided innumerable benefits. They are source of water for domestic use, irrigation and hydropower. They have important social and economic benefits as a result of tourism and recreation and are culturally and aesthetically important for people throughout the world (M. Rajsekhar et al., 2009).

Intake tower is a structure located in a water source, with his key role of allowing inlet of water and extracting water from that source through a discharge pipe up to the water utilities, in order to be treated, disinfected and delivered to the population.

This paper is doing a clear comparison and analysis of the raw water quality parameters taken from different levels of Brădișor reservoir water depth.

The article aims to analyze and promote the most accurate situation of water intakes in lakes, from different water depths, regarding directly water quality parameters, which clearly influence the water treatment process, taking into consideration OPEX (Operating Expenses) of water treatment.

\footnotetext{
1 Technical University of Civil Engineering Bucharest, e-mail: florianmartan@gmail.com ungureanudanie1192@yahoo.com
} 


\section{DATA AND METHODS}

\subsection{Data and methods used}

\subsubsection{Water quality parameters}

In this paper, the authors are taking into consideration both, the biological parameters of water quality, as well like the physical-chemical parameters, as following:

\section{Biological parameters:}

- Phytoplankton, phytobenthos, macrophytes, macroinvertebrates;

- Fish fauna (species, abundance and age structure);

\section{Physico-chemical parameters:}

- Thermal conditions: temperature;

- Oxygen water rate: dissolved oxygen, $\mathrm{CBO}_{5}, \mathrm{CCO}-\mathrm{Cr}$;

- Acidification state: $\mathrm{pH}$;

- Salinity conditions: conductivity;

- Nutrient conditions: $\mathrm{N}-\mathrm{NO}_{2}, \mathrm{~N}-\mathrm{NO}_{3}, \mathrm{~N}-\mathrm{NH}_{4}$, full N, P-PO $\mathrm{PO}_{4}$, full P;

- Colour;

- $\mathrm{Fe}$;

- Turbidity;

- Hardness.

Also, the physical parameters, such as sediments content, floats or ice can be a problem, blocking the discharge pipes, or creating problems in water treatment process.

The assessment of the ecological status/ecological potential for surface water bodies is performed by integrating quality parameters (biological, physico-chemical and specific pollutants), taking into account the worst-case scenario.

For surface water categories, the assessment of the ecological status is performed to 5 quality states, respectively: very good, good, moderate, weak and bad.

The assessment of the ecological status and the ecological potential for surface waters was performed according to the Water Law no. 107/1996 with the subsequent modifications and completions, based on methodologies regarding the systems of classification and global assessment of the surface water status elaborated according to the requirements of the Water Framework Directive 2000/60/EEC.

The assessment of the chemical state of a surface water body is made taking into account the reglementations of the Directive 2013/39/EC that is changing and completing the Directive 2008/105/EC, regarding the environmental quality standards in the field of water and of the GD 570/2016, regarding the approval of the Program for gradual elimination of discharges, emissions and losses of priority hazardous substances and other measures for the main pollutants.

Brădișor reservoir is monitored in two sections: middle lake and intake tower. 


\subsubsection{Intake tower}

Brădișor dam is located at Carpathian Mountains between Malaia and Pascoaia localities and the lake from upstream is tributary to Lotru river, that is entirely regularized and arranged (from the point of view of flood impact, and energetical point of view).

Brădişor reservoir is framed in typology ROLA08 (being framed by the Water Framework Directive) and is located at altitude of $457 \mathrm{mdMN}$ (meters above Black Sea Level), with the dam height of $62 \mathrm{~m}$. The surface of the lake at the normal retention level is $226 \mathrm{ha}$, and the volume is $3.225 \mathrm{mil}$. cubic meter of water. It is used for energy, drinking water supply and fish farming. The most important utilities of the lake is the generation of energy through the hydroelectric power station (with an installed power of $115 \mathrm{MW}$ ) and drinking water supply for Ramnicu-Valcea city.

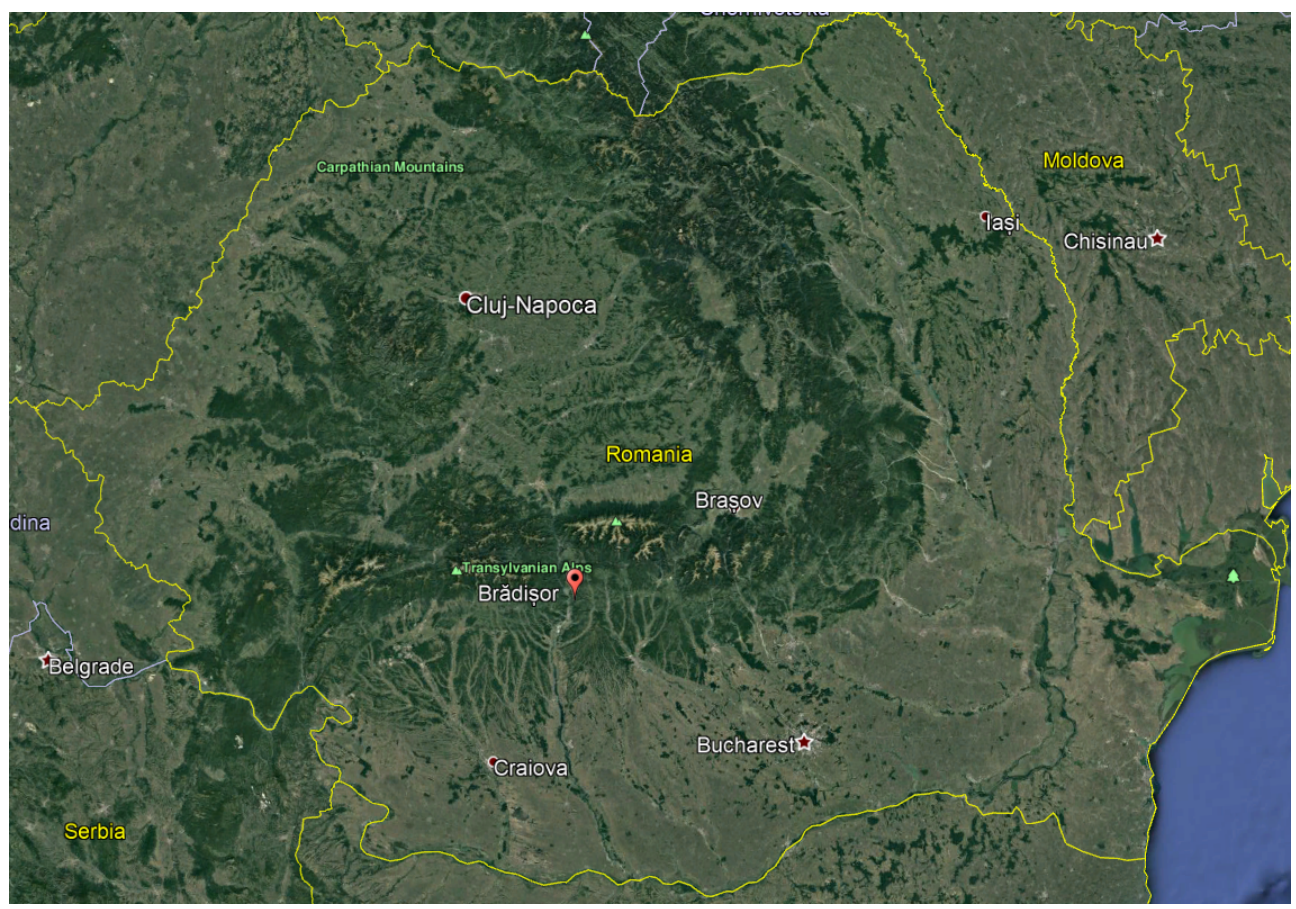

Fig. 1. Brădișor reservoir position in Romania (Google Earth Pro)

The water supply of Ramnicu Valcea city is done through the intake towers and a discharge pipe from the water intake tower with a nominal diameter of $1200 \mathrm{~mm}$ that is carrying a total flow of $1.2 \mathrm{mc} / \mathrm{s}$ raw water up to "Valea lui Stan" drinking water treatment plant, in order to be treated and delivered to the population.

As is presented below, the raw water quality parameters are very changed, also regarding a time schedule, or a site sampling, reason for why the best intake structure 
used for withdrawing water from Brădișor reservoir are intake towers that have more openings located at different depths.

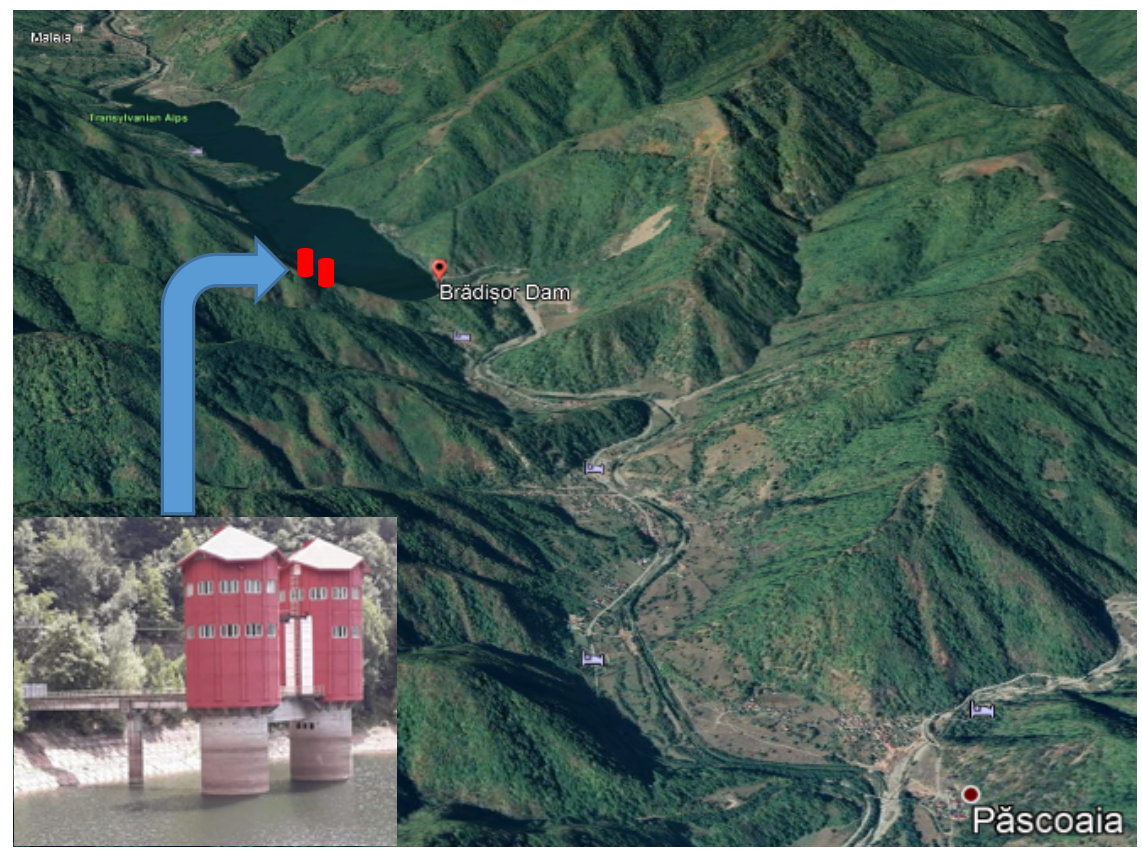

Fig. 2. Brădișor reservoir - 3D Map (Google Earth Pro)

The main opening is located at altitude of $410.84 \mathrm{mdMN}$ and the secondary opening is located at altitude of $422.60 \mathrm{mdMN}$.

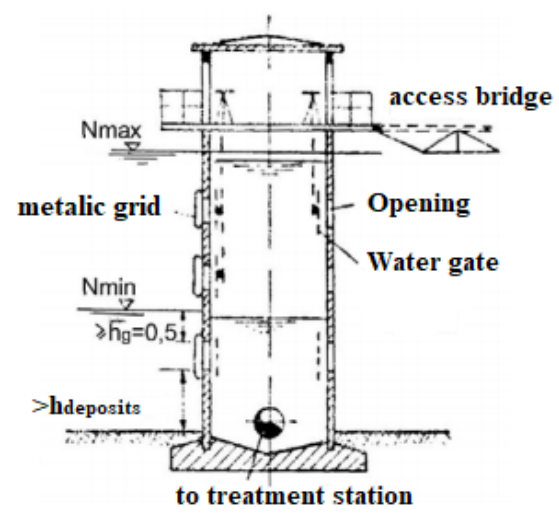

Fig. 3. General intake tower structure

The openings of the intake are positioned above the sediments deposit located at the bottom of the lake. To protect the downstream equipment, the openings are equipped with metallic grid, protected by frozen trough additional systems. 


\section{RESULTS AND DISCUSSIONS}

Acording to the measurements made on years 2015-2019 by Olt Water Basin Administration, the results are as follows:

\section{Biological parameters}

In 2015-2019, from the point of view of the biological parameters monitored (phytoplankton and phytobenthos), Brădișor reservoir state was good potential.

Table 1. Biological parameters determinations

\begin{tabular}{|c|c|c|c|c|c|c|}
\hline \multicolumn{7}{|c|}{ Biological parameters } \\
\hline Yr. & Phytoplankton & Phytobenthos & Macrophytes & Macroinvertebrates & Fish & $\begin{array}{c}\text { Biological } \\
\text { parameters }\end{array}$ \\
\hline $\mathbf{2 0 1 5}$ & Very good & Very good & N/A & N/A & N/A & Very good \\
\hline $\mathbf{2 0 1 6}$ & Good & Good & N/A & N/A & N/A & Good \\
\hline $\mathbf{2 0 1 7}$ & Good & Good & N/A & N/A & N/A & Good \\
\hline $\mathbf{2 0 1 8}$ & Good & Good & N/A & N/A & N/A & Good \\
\hline $\mathbf{2 0 1 9}$ & Good & Good & N/A & N/A & N/A & Good \\
\hline
\end{tabular}

\section{$\underline{\text { Physico-chemical parameters }}$}

The physico-chemical parameters monitored in 2015-2019, in order to evaluate the reservoir potential, have the following average values:

Table 2. Physico-chemical parameters determinations

\begin{tabular}{|c|c|c|c|c|c|c|}
\hline $\begin{array}{l}\text { Water } \\
\text { body }\end{array}$ & $\begin{array}{c}\text { Water body } \\
\text { code }\end{array}$ & $\begin{array}{c}\text { Typolog } \\
\mathrm{y}\end{array}$ & Parameters & $\begin{array}{c}\text { Valu } \\
\text { e }\end{array}$ & $\begin{array}{c}\text { State/Potenti } \\
\text { al }\end{array}$ & $\begin{array}{c}\text { State/Final } \\
\text { potential }\end{array}$ \\
\hline \multirow{9}{*}{$\begin{array}{c}\text { Lotru } \\
\text { Brădişor } \\
\text { reservoir - } \\
\text { Strongly } \\
\text { modified }\end{array}$} & \multirow{9}{*}{$\begin{array}{c}\text { ROLW8.1.135_ } \\
\text { B4 }\end{array}$} & \multirow{9}{*}{$\begin{array}{l}\text { ROLA0 } \\
\quad 8\end{array}$} & $\begin{array}{l}\text { Dissolved } \\
\text { oxygen } \\
{[\mathrm{mgO} / / 1]}\end{array}$ & 9,646 & Very good & \multirow{9}{*}{ Good } \\
\hline & & & $\mathrm{CBO} 5[\mathrm{mg} / \mathrm{l}]$ & 1,991 & Very good & \\
\hline & & & $\begin{array}{l}\mathrm{CCO}-\mathrm{Cr} \\
{[\mathrm{mg} / \mathrm{l}]}\end{array}$ & 5,416 & Very good & \\
\hline & & & $\begin{array}{l}\mathrm{N}-\mathrm{NH} 4 \\
{[\mathrm{mg} / \mathrm{l}]}\end{array}$ & 0,014 & Very good & \\
\hline & & & $\begin{array}{l}\mathrm{N}-\mathrm{NO} 2 \\
{[\mathrm{mg} / \mathrm{l}]}\end{array}$ & 0,006 & Good & \\
\hline & & & $\begin{array}{l}\mathrm{N}-\mathrm{NO} 3 \\
{[\mathrm{mg} / \mathrm{l}]}\end{array}$ & 0,341 & Very good & \\
\hline & & & $\mathrm{N}$ total $[\mathrm{mg} / \mathrm{l}]$ & 0,423 & Very good & \\
\hline & & & P-PO4 [mg/l] & 0,018 & Good & \\
\hline & & & $\begin{array}{l}\mathrm{P} \text { total } \\
{[\mathrm{mg} / \mathrm{l}]}\end{array}$ & 0,023 & Very good & \\
\hline
\end{tabular}

To evaluate the raw water quality from Brădișor reservoir in order to purify in drinking water treatment plant Valea lui Stan, during the years 2015-2019, the average 
of the main physical-chemical constituents (turbidity, colour, $\mathrm{pH}$, oxidability, $\mathrm{N}-\mathrm{NH}_{4}$, $\mathrm{N}-\mathrm{NO}_{2}, \mathrm{Fe}$, hardness and conductivity) it was analyzed, as follows:

Table 3. Main physical-chemical constituents

\begin{tabular}{|c|c|c|c|c|c|c|}
\hline \multirow{2}{*}{ Yr. } & \multicolumn{2}{|c|}{ Turbidity [\% of max value] } & \multicolumn{2}{c|}{ Colour [\% of max value] } & \multicolumn{2}{c|}{ pH \% [of max value] } \\
\cline { 2 - 7 } & $\begin{array}{c}\text { Main } \\
\text { opening }\end{array}$ & $\begin{array}{c}\text { Secondary } \\
\text { opening }\end{array}$ & $\begin{array}{c}\text { Main } \\
\text { opening }\end{array}$ & $\begin{array}{c}\text { Secondary } \\
\text { opening }\end{array}$ & $\begin{array}{c}\text { Main } \\
\text { opening }\end{array}$ & $\begin{array}{c}\text { Secondary } \\
\text { opening }\end{array}$ \\
\hline $\mathbf{2 0 1 5}$ & 2,59 & 3,81 & 14 & 24 & 7,7 & 7,6 \\
\hline $\mathbf{2 0 1 6}$ & 2,96 & 3,99 & 16 & 25 & 7,6 & 7,6 \\
\hline $\mathbf{2 0 1 7}$ & 3,02 & 4,03 & 17 & 27 & 7,6 & 7,6 \\
\hline $\mathbf{2 0 1 8}$ & 3,61 & 4,32 & 19 & 29 & 7,6 & 7,6 \\
\hline $\mathbf{2 0 1 9}$ & 2,45 & 4,27 & 13 & 22 & 7,5 & 7,6 \\
\hline
\end{tabular}

\begin{tabular}{|c|c|c|c|c|c|c|}
\hline \multirow{2}{*}{ Yr. } & \multicolumn{2}{|c|}{ Oxidability [\% of max value] } & \multicolumn{2}{|c|}{ N-NH4 [\% of max value] } & \multicolumn{2}{|c|}{ N-NO2 [\% of max value] } \\
\cline { 2 - 7 } & $\begin{array}{c}\text { Main } \\
\text { opening }\end{array}$ & $\begin{array}{c}\text { Secondary } \\
\text { opening }\end{array}$ & $\begin{array}{c}\text { Main } \\
\text { opening }\end{array}$ & $\begin{array}{c}\text { Secondary } \\
\text { opening }\end{array}$ & $\begin{array}{c}\text { Main } \\
\text { opening }\end{array}$ & $\begin{array}{c}\text { Secondary } \\
\text { opening }\end{array}$ \\
\hline $\mathbf{2 0 1 5}$ & 2,30 & 2,04 & 0,014 & 0,020 & 0,006 & 0,005 \\
\hline $\mathbf{2 0 1 6}$ & 2,21 & 2,08 & 0,015 & 0,020 & 0,005 & 0,006 \\
\hline $\mathbf{2 0 1 7}$ & 2,39 & 2,07 & 0,017 & 0,021 & 0,005 & 0,006 \\
\hline $\mathbf{2 0 1 8}$ & 2,49 & 2,08 & 0,020 & 0,020 & 0,005 & 0,005 \\
\hline $\mathbf{2 0 1 9}$ & 2,25 & 2,01 & 0,025 & 0,022 & 0,005 & 0,005 \\
\hline
\end{tabular}

\begin{tabular}{|c|c|c|c|c|c|c|}
\hline \multirow{2}{*}{ Yr. } & \multicolumn{2}{|c|}{ Fe [\% of max value] } & \multicolumn{2}{c|}{ Hardness [\% of max value] } & \multicolumn{2}{c|}{ Conductivity [\% of max value] } \\
\cline { 2 - 7 } & $\begin{array}{c}\text { Main } \\
\text { opening }\end{array}$ & $\begin{array}{c}\text { Secondary } \\
\text { opening }\end{array}$ & $\begin{array}{c}\text { Main } \\
\text { opening }\end{array}$ & $\begin{array}{c}\text { Secondary } \\
\text { opening }\end{array}$ & $\begin{array}{c}\text { Main } \\
\text { opening }\end{array}$ & $\begin{array}{c}\text { Secondary } \\
\text { opening }\end{array}$ \\
\hline $\mathbf{2 0 1 5}$ & 51 & 55 & 2,05 & 2,03 & 75,46 & 73,09 \\
\hline $\mathbf{2 0 1 6}$ & 55 & 60 & 1,90 & 1,99 & 77,59 & 74,01 \\
\hline $\mathbf{2 0 1 7}$ & 57 & 60 & 1,92 & 1,98 & 77,20 & 74,23 \\
\hline $\mathbf{2 0 1 8}$ & 62 & 63 & 1,86 & 1,90 & 78,45 & 74,56 \\
\hline $\mathbf{2 0 1 9}$ & 45 & 48 & 1,80 & 1,90 & 74,20 & 73,60 \\
\hline
\end{tabular}

Charts which comparing the results shown above are presented in the following:

As it can be observed from the tables above, the time variation of the physical parameters of water depending on the sampling depth layer of water source (intake towers) clearly shows a superiority of the parameters analyzed in the surface layer of the water. This leads to a clear conclusion that the water treatment in optimal conditions is done by taking water from the surface layers of the water source (Brădişor reservoir). The water intakes tower that are extracting water from the deeper layers of the reservoir make the treatment water process much harder, and much expensive for the water company, with higher energy consumption and increased chemical consumption (OPEX).

Making a strictly and objectively analyze of the water parameters in surface and deeper layers, we can conclude:

- there is a lower turbidity of the water taken from the surface layer compared to the water taken from the depth layer, the lake acting and fulfilling the function of natural sediment settler; 


\section{Physical parameters}

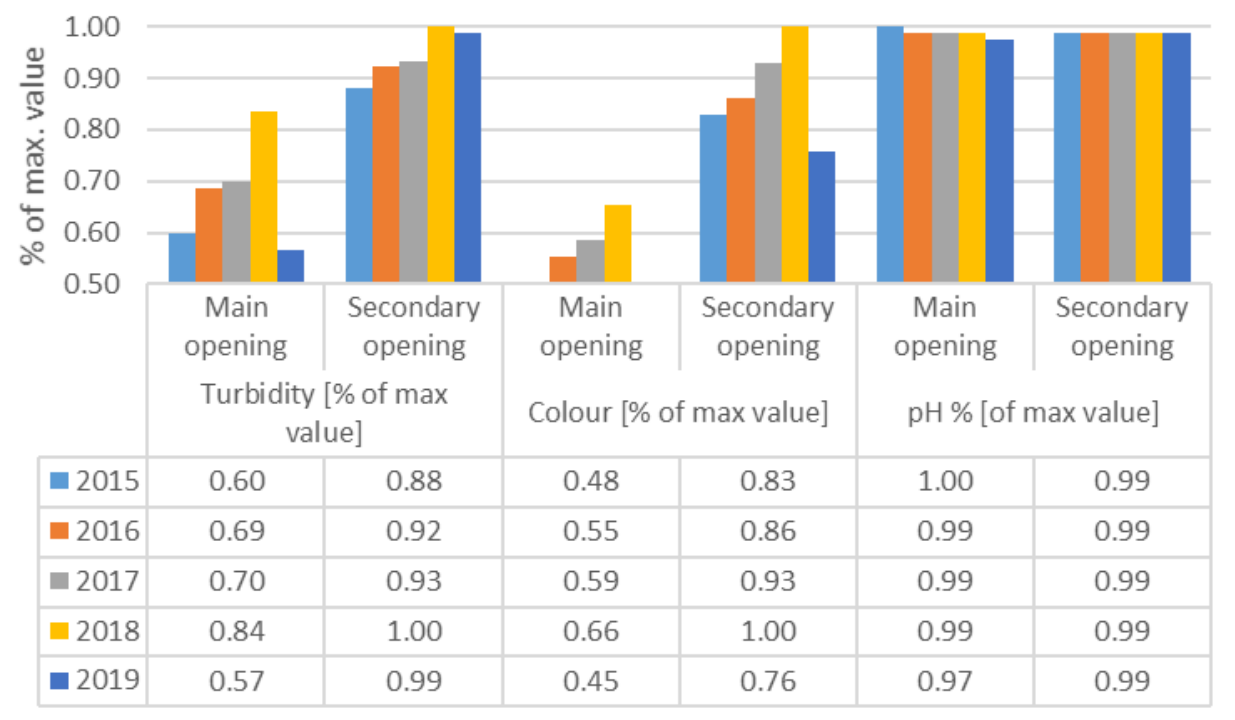

Fig. 4. Physical parameters from Brădișor reservoir (\% of max. value)

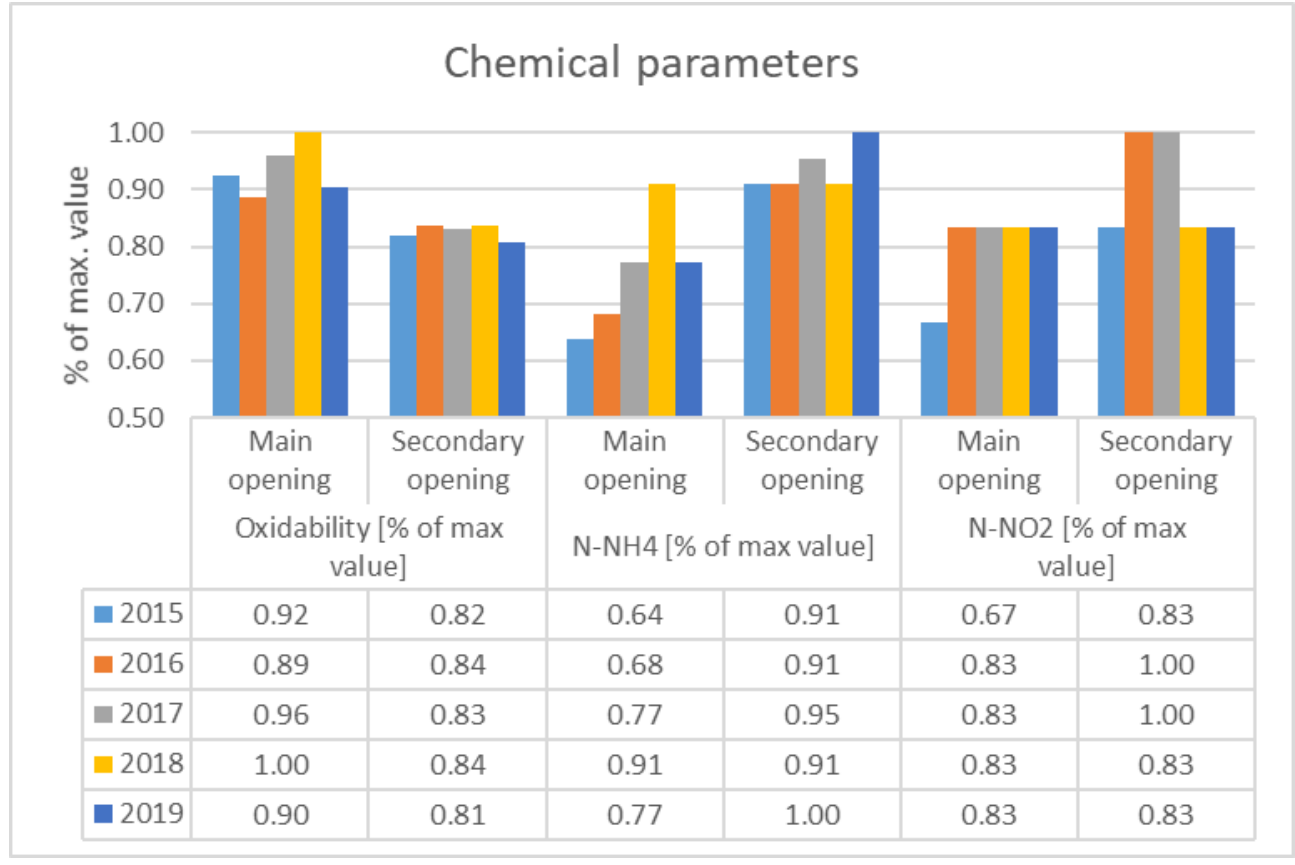

Fig. 5.1 Chemical parameters from Brădișor reservoir (\% of max. value) 


\section{Chemical parameters}

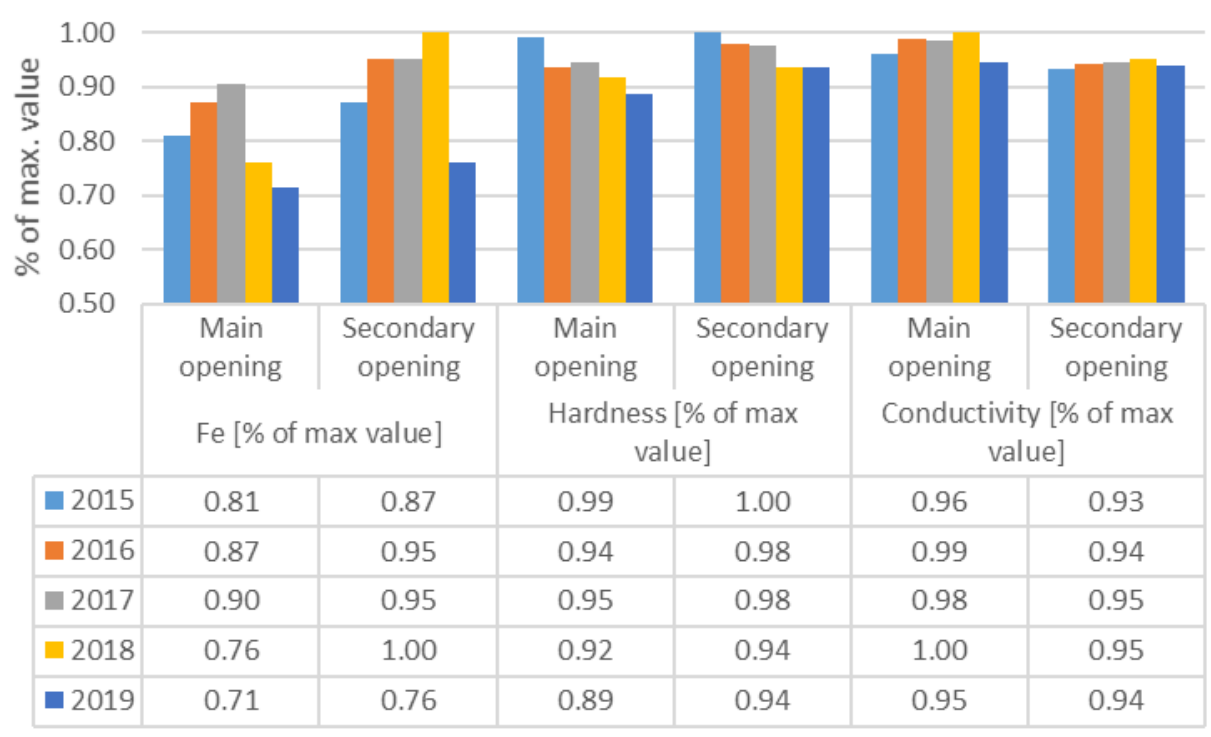

Fig. 5.2 Chemical parameters from Brădișor reservoir (\% of max. value)

- colour, which is dependent on turbidity; it is observed that in rainy periods the turbidity is shown with higher values, and also the colour is changing in the same way as turbidity;

- $\mathrm{pH}$, which evaluates the level of acidity (or basicity) of raw water, its variations are insignificant, the value being approximately constant;

- oxidability, analyzed graphically it is observed that it has higher values on the surface layers, the water being more aerated (higher oxygen content);

- N-NH4, with obvious higher values (as shown in the chart above) in the depth layers of the lake; again the water easier to be treated is in the surface layer;

- N-NO2, as well as N-NH4, with higher values in the depth layers;

- Fe, with lower values in the surface layer; considering that the oxidability parameter has high values in the surface layer, in the treatment of water the elimination of $\mathrm{Fe}$ is much easier, it is oxidized with the help of oxygen in the water, helped also by the addition of chlorine, and filtered through the filtration layers in the DWTP;

- hardness, with higher values in the depth layer, above the allowed limit for drinking water;

- conductivity, with higher values on the deeper layers, also being advised to take water from the surface layers, which have lower conductivity. 


\section{CONCLUSIONS}

The analyze of raw water quality parameters place Brădișor water body into a good ecological state potential, being decreased from the initial potential "very good" - that was framed in 2015.

Comparing the physical and chemical constituents in correlation with water depth, an historical data base analysis was done, in order to evaluate the most accurate situation of water intakes in lakes, regarding directly water quality parameters, which clearly influence the water treatment process (taking into consideration OPEX of water treatment).

Analyzing different levels of intake water tower, we can say that the best level of extracting water is the higher level, where water parameters can easily be treated in Valea lui Stan water treatment plant, and OPEX is lower than the lower level of water intake.

In fact, these aspects are reflected in operational activities of Valea lui Stan treatment plant where the employees of the regional operator APAVIL VALCEA have decided to use in the last 4 years only the surface opening of the intake towers.

\section{REFERENCES}

1. Abdelazim M. Negm, Gheorghe Romanescu, Martina Zelenakova. (2019), Water Resources Management in Romania.

2. Altan Abdulamit (2015), Courses on Hydrotehnical Construction, Tehnical University of Civil Engineering, Bucharest.

3. Corneliu Dan Hancu. (2004), Prize de apa si aductiuni, Bucuresti, Matrix Rom.

4. European Comision Directorate General Joint Research Center, Institute for Environment and Sustainability (2007), Ecological Quality Ratios for Ecological Quality Assessment in Inland and Marine Waters.

5. Ministry of Waters and Forests-Romania. (2019), Environmental management plan and environmental guidelines for integrated nutrient pollution control project.

6. M. Rajashekhar, K. Vijaykumar, Parveen Zeba. (2009), Zooplankton diversity of three freshwater lakes with relation to trophic status, Gulbarga district, North-East Karnataka, South India

7. National Administration „Romanian Waters”. (2016), Regulamentul de exploatare al acumularii Brădișor.

8. National Administration „Romanian Waters”. (2013), Sinteza calitatii apei in Romania.

9. Olt Water Basin Administration. (2013), Sinteza anuala privind protectia calitatii apelor pentru bazinul hidrografic Olt.

10. Order EWM no. 161/2006, approving the Norms concerning the classification of surface water quality in order to establish the ecological status of water bodies 
11. Sandu M., Racoviteanu G. (2016), Manual pentru inspectia sanitara si monitorizarea calitatii apei in sistemele de alimentare cu apa, Bucuresti, Conspress. 